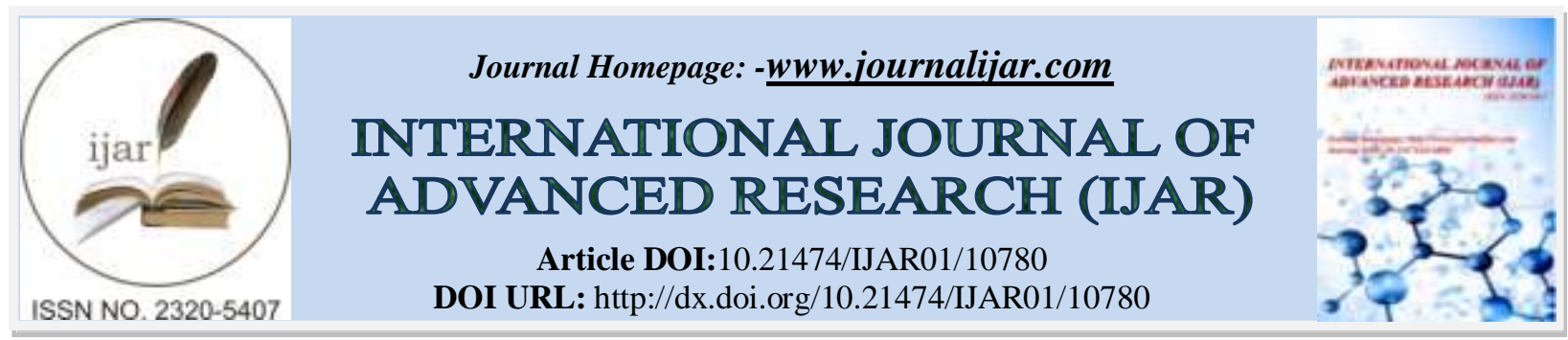

RESEARCH ARTICLE

\title{
DEVELOPMENT, PHYSICO-CHEMICAL AND MICROBIOLOGICAL CHARACTERIZATION OF A CUBE BROTH BASED ON "LANHOUIN" STABILIZED USING PLANT EXTRACTS
}

\section{A.C. Allagbé ${ }^{1}$, R. G. Degnon ${ }^{2}$ and C.T.R. Konfo ${ }^{3}$}

1. Research Scholar, Laboratory of Study and Research in Applied Chemistry, Polytechnic School of AbomeyCalavi, University of Abomey-Calavi.

2. Lecturer, Laboratory of Study and Research in Applied Chemistry, Polytechnic School of Abomey-Calavi, University of Abomey-Calavi.

3. Assistant Professor, Food and Bioresources and Human Nutrition Science and Technology Laboratory,Schools of Science and Techniques for Preservation and Processing of Agricultural Products, National University of Agriculture, PO Box114, Ayita (Sakété), Benin

\section{Manuscript Info}

\section{Manuscript History}

Received: 10 February 2020

Final Accepted: 12 March 2020

Published: April 2020

Key words:-

Food Broth, cube, "Lanhouin", Plant

Extracts, Innovation

\begin{abstract}
The present study aims to limit the consumption of synthetic broths by developing a natural broth based on "lanhouin" flour stabilized with plant extracts for their antifungal and antioxidant activities.To do this, the essential oils of Pimenta racemosa, Cymbopogon citratus and the powder of Curcuma longa were used at different doses. The physicochemical characterization of the samples of cube broths produced indicates that these latter have a water content of varied from 45.52 to $50.54 \%$ and $\mathrm{pH}$ varying from to 6.82 and 7.58. Microbiological analyzes revealed the presence of total mesophilic flora and Staphylococcus spp in all samples. The Sulfito-Reducing Anaerobes (ASR) were counted in 05 samples out of 13 analyzed. The fungal flora was present in 03 samples out of 13 analyzed. On the other hand, there is a total absence of total coliforms in the different samples. It then becomes necessary to assess the acceptability of the innovative product developed with a view to its future development
\end{abstract}

Copy Right, IJAR, 2020,. All rights reserved.

\section{Introduction:-}

Fisheries and aquaculture remain, for hundreds of millions of people around the world, activities of primary importance for food, nutrition, the acquisition of income or livelihoods (FAO, 2016; Fall et al., 2018). These activities worldwide provided 167.2 million tonnes in 2014, $93.4 \%$ of which is produced by fisheries and $73.8 \%$ by aquaculture. More than 200 million Africans regularly eat fish either fresh or most often smoked or dried (World Fish Center, 2005).In Benin, this sector plays a major role in the national economy with a contribution of $3 \%$ to GDP (Ayoubi and Failler, 2013). However, the conservation of fishery products in landing sites and sales areas, remains a major problem, due to their very perishable nature, the lack of adequate infrastructure and local climatic conditions very favorable to a degradation of the products landed in a few hours (Fall et al., 2018). The percentage of post-harvest losses and deterioration in product quality is high, with all the associated risks for consumer health (FAO, 2016). Like other countries in the West African sub-region, post-catch losses are estimated at around 20\%, despite the efforts made each year, by conserving fresh fish by various traditional techniques, including fermentation to produce Lanhouin (Anihouvi et al., 2005). 
In addition, cubes are essential in most African cuisines. These culinary broths are however harmful to health. While this information is not new to some, it remains difficult for many to accept. ... The famous broths present dangers to consumers because of their high content of salt and chemicals such as monosodium glutamate, disodium inosinate and disodium gyanylate ... More and more African nutritionists are trying to oppose the excessive use of these products. In Mali, in 2010, a workshop devoted to "Dangers linked to food additives" was held at the Intrenational Conference Center of Bamako. It brought together experts (veterinarians, university researchers, doctors ...), but also representatives of the Ministry of Health, health laboratories, and agencies in charge of food safety. Their conclusions are final; they reveal that the small palate seduction cubes can cause heart problems, hypo or hypertension, gastric diseases, behavioral disorders in children, swelling of the prostate, Parkinson's disease or that Alzheimer's ... They can also reduce libido, trigger bleeding and urogenital infections (Clamay, 2016).

In order to avoid the harmful consequences of cube broths on their health, more and more consumers are turning to natural products such as "lanhouin". "Lanhouin" is a natural flavor enhancer obtained by fermentation, salting and drying of the fish (Dossou-Yovo et al., 2011). It is produced on an artisanal scale by a spontaneous fermentation over which very little control can be exerted, with the obtaining of a final product often of variable quality, with risks of quality defect, in particular the formation of toxic substances such as biogenic amines including histamine (Anihouvi et al., 2006). Likewise, the use of petroleum or petrol and various insecticides against insects during production can constitute potential risks of poisoning (Anihouvi et al., 2005). It is therefore urgent to look for natural products that are slightly or not toxic in order to conserve / stabilize the "lanhouin". In this perspective, a study conducted by Anihouvi et al. (2014) allowed the improvement of the production process of "lanhouin" through, the insertion of a step of immersion of fermented salted fillets, in a solution of garlic extract and lemon juice with bacteriostatic action. However, the use of aromatic plant extracts as preservatives could constitute a credible alternative as it guarantees the preservation of consumers' health (Burt, 2004; Konfo et al., 2015). Indeed, several studies have demonstrated the antifungal and antibacterial properties of essential oils (Burt, 2004; Dègnon et al., 2013). They are known both for their antioxidant, flavoring, antimicrobial properties and their reduced toxicity compared to that of chemical preservatives (Bassolé et al., 2001). The objective of this study is to develop a technology for the production of broth (cube) from salted and dried fermented fish meal "lanhouin" stabilized and improved with essential oils and turmeric powder.

\section{Material and Methods:- \\ Raw Materials:}

The plant materials used in this study werePimenta racemosa and Cymbopogon citratusessential oils and Curcuma longa powder. We also used cassava starch powder and samples of fish (species).

\section{Improved food broth production manufacturing process:}

Fermented, salted and dried "lanhouin" fish is obtained by spontaneous fermentation following a process including washing and or trimming, ripening, sorting, salting, fermentation and drying or draining. Washing and / or trimming consists in washing, gutting and, if necessary, scaling the fish. Depending on the case, the trimming operation can precede or succeed the maturation which consists in leaving the fish without treatment until its softening. Untrimmed fish is immersed in seawater contained in a basin (for 10 to 15 hours). The previously eviscerated fish is placed in a basin without seawater and left for the same period; the "soft fish" is obtained. The soft fish are then sorted then salted and put into fermentation. The salt is introduced into the evisceration slot under the lid, in the gills and passed over the whole body of the fish. Fermentation can last 3 to 8 days. The fish are then left to dry in the sun for 2 to 4 days. We obtain salted, fermented and dried fish "Lanhouin". Then the head of lanhouin isremoving and the remaining part is ground to obtain "lanhouin" flour. To this flour, essential oil of Pimenta racemosa or Cymbopogon citratus, Curcuma longa powder and cassava starch powder in the appropriate proportions (Table 1) were added for each sample. The whole is then dried for 2 hours at $37^{\circ} \mathrm{C}$.). The obtained broths werefinally packed (Figure 1). 

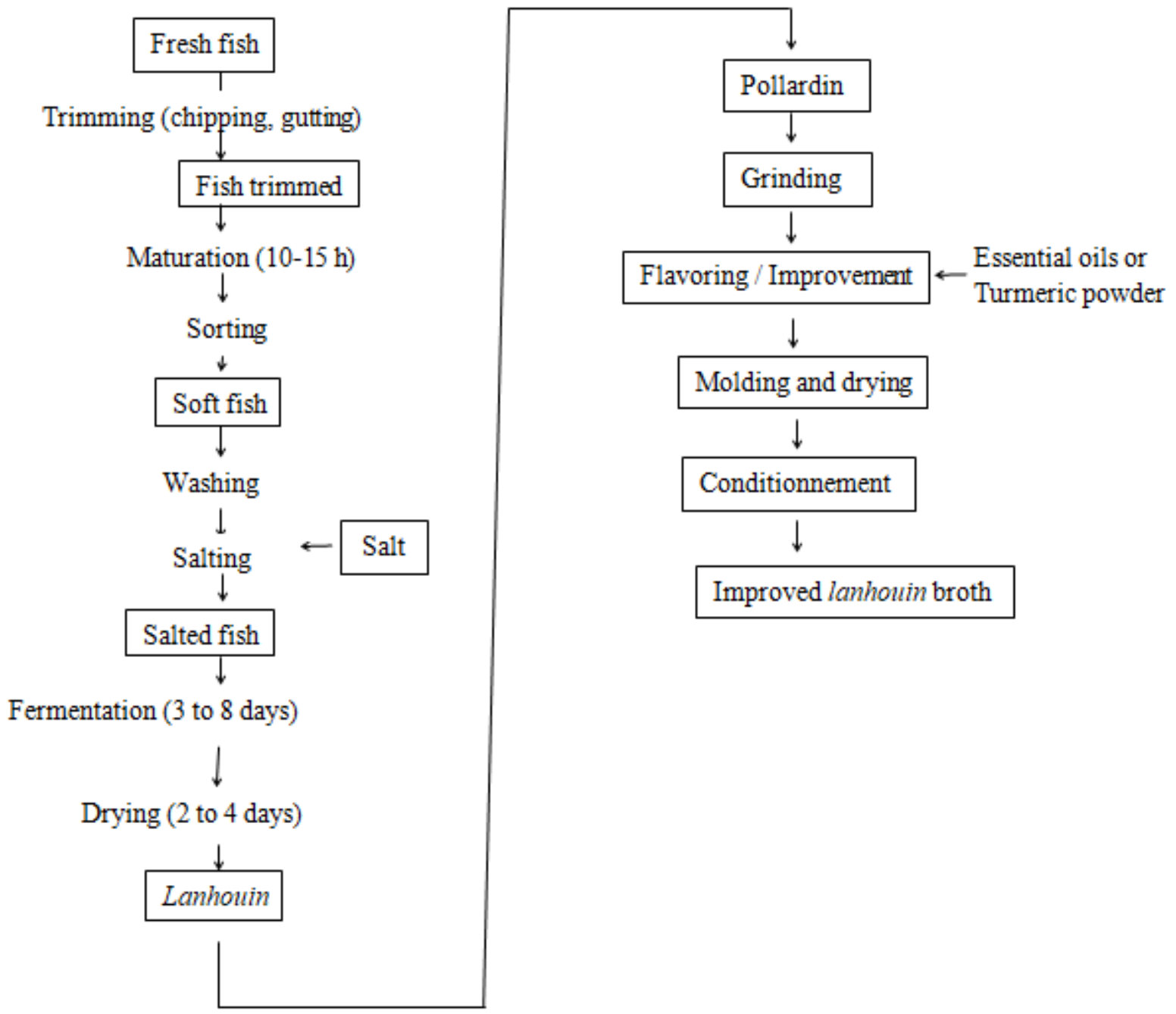

Figure1:- Manufacturing process for improved broth production based on lanhouin.

Mixing plan:

The mixing plan tested during this work is summarized in Tables 1 and 2.

Table1:- Mixing plan with Cymbopogon citratusessential oil.

\begin{tabular}{|c|c|c|c|c|}
\hline Constituents & $\begin{array}{l}\text { Propotions of } \\
\text { Lanhouin } \\
\text { flour(\%) }\end{array}$ & $\begin{array}{l}\text { Propotions of } \\
\text { turmeric powder(\%) }\end{array}$ & $\begin{array}{l}\text { Propotionsof } \\
\text { Binder }(\%)\end{array}$ & $\begin{array}{l}\text { Cymbopogon } \\
\text { citratus essential } \\
\text { oil doses }(\mu 1 / \mathrm{g})\end{array}$ \\
\hline $\mathrm{E}_{0}$ : Témoin & 100 & 0 & 0 & 0 \\
\hline $\mathrm{E}_{1 \mathrm{a}}$ & \multirow{3}{*}{50} & 10 & 40 & \multirow{3}{*}{1,5} \\
\hline $\mathrm{E}_{2 \mathrm{a}}$ & & 20 & 30 & \\
\hline$E_{3 a}$ & & 40 & 10 & \\
\hline$E_{1 b}$ & \multirow{3}{*}{50} & 10 & 40 & \multirow{3}{*}{2,5} \\
\hline $\mathrm{E}_{2 \mathrm{~b}}$ & & 20 & 30 & \\
\hline$E_{3 b}$ & & 40 & 10 & \\
\hline
\end{tabular}


Table 2:- Mixing plan with Pimenta racemosa essential oil.

\begin{tabular}{|c|c|c|c|c|}
\hline Constituants & $\begin{array}{l}\text { Propotions of } \\
\text { «Lanhouin » flour } \\
(\%)\end{array}$ & $\begin{array}{lr}\text { Propotions } & \text { of } \\
\text { turmeric } & \text { powder } \\
(\%) & \end{array}$ & $\begin{array}{l}\text { Propotions } \\
\text { Binder }(\%)\end{array}$ & $\begin{array}{l}\text { Pimenta } \\
\text { Racemosa } \\
\text { essential oil doses } \\
(\mu \mathrm{l} / \mathrm{g})\end{array}$ \\
\hline $\mathrm{E}_{0}$ : Témoin & 100 & 0 & 0 & 0 \\
\hline $\mathrm{E}_{1 \mathrm{a}}^{\prime}$ & \multirow{3}{*}{50} & 10 & 40 & \multirow{3}{*}{1,5} \\
\hline$E_{2 a}^{\prime}$ & & 20 & 30 & \\
\hline$E_{3 a}^{\prime}$ & & 40 & 10 & \\
\hline$E_{1 b}^{\prime}$ & \multirow{3}{*}{50} & 10 & 40 & \multirow{3}{*}{2,5} \\
\hline$E_{2 b}^{\prime}$ & & 20 & 30 & \\
\hline$E_{3 b}^{\prime}$ & & 40 & 10 & \\
\hline
\end{tabular}

Microbiological analysis:

Samples microbiological parameters were evaluated by using standard methods. Thus, the total mesophilic aerobic flora was enumerated by inoculation on the Plate Count Agar medium (PCA) and incubation at $30{ }^{\circ} \mathrm{C}$ for $24-48 \mathrm{~h}$ (NF V08-051), whereas positive coagulasse Staphylococci was tested on Baird Parker medium with incubation at $37^{\circ} \mathrm{C}$ for 24-48 (NF EN ISO 6888-1 / A1). The Anaerobic Sulpho-Reducing Bacteria were investigated on Tryptone Sulfite Neomycin (TSN) agar with incubation at $46^{\circ} \mathrm{C}$ for 20h (NF ISO 15213). The total coliforms were searched on the Violet Red Bile Lactose medium (VRBL) with incubation at $30^{\circ} \mathrm{C}$ for $24 \mathrm{~h}$ (NF V08-050), while yeasts and molds were isolated on Sabouraud medium with chloramphenicol with incubation at $25{ }^{\circ} \mathrm{C}$ for 3 to 5 days (NF V08059).

\section{Physicochemical analysis:}

The $\mathrm{pH}$ was measured with a digital pH-meter (TOOGOO(R) (PH-009(I)) equipped with an electrode and a digital display screen. On a mixture obtained from $10 \mathrm{~g}$ of sample ground in $90 \mathrm{ml}$ of distilled water. The measurements were taken by immersing the electrode of the $\mathrm{pH}$ meter in $10 \mathrm{ml}$ of the filtrate obtained from the mixture.

Dry matter was determined according to AOAC (2008). Five (05) grams of each sample of "lanhouin" cube broth was weighed in crucibles which were then placed in an oven at $105^{\circ} \mathrm{C}$ for 48 hours. After drying, the crucibles containing the samples were cooled in a desiccator and then weighed again. The dry matter content (DMC) of each sample was obtained by the formula:

$$
\operatorname{DMC}(\%)=\frac{\mathbf{P 1}-\mathbf{P o}}{\mathbf{P}} \times \mathbf{1 0 0}
$$

- P1 $(g)=$ weight of the sample and the crucible after passage through the oven,

- Po $(g)=$ weight of the empty crucible,

- P $(\mathrm{g})=$ weight of the sample before going to the oven;

The water content (WC) itself is determined by the formula:

$\mathrm{WC}(\%)=100$ - DMC $(\%)$

\section{Statistical analysis:}

Data from three independent replicate trials were subjected to statistical analysis using Microsoft Excel 2010.

\section{Résultats:-}

The pictures below show lanhouin flour and a cube broth produced 


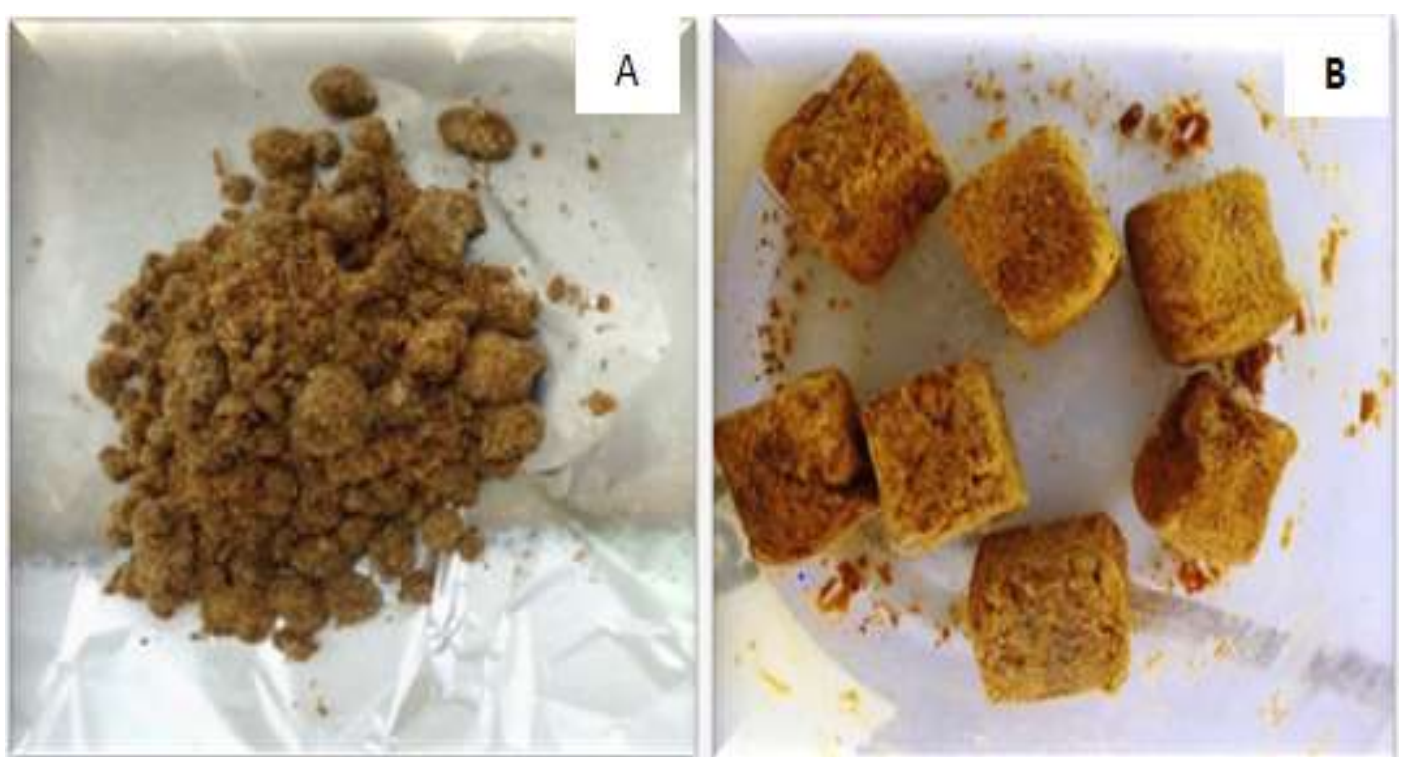

Figure 2:- Farine de lanhouin (A) et bouillon cube à base de lanhouin (B).

\section{Physicochemical characteristics of improved food broth:}

From the analysis of Figures 1 and 2, it appears that the different samples of cube broth water contents varied from 45.52 and $50.54 \%$ while the $\mathrm{pH}$ values obtained variedfrom 6.82 to 7.58 .

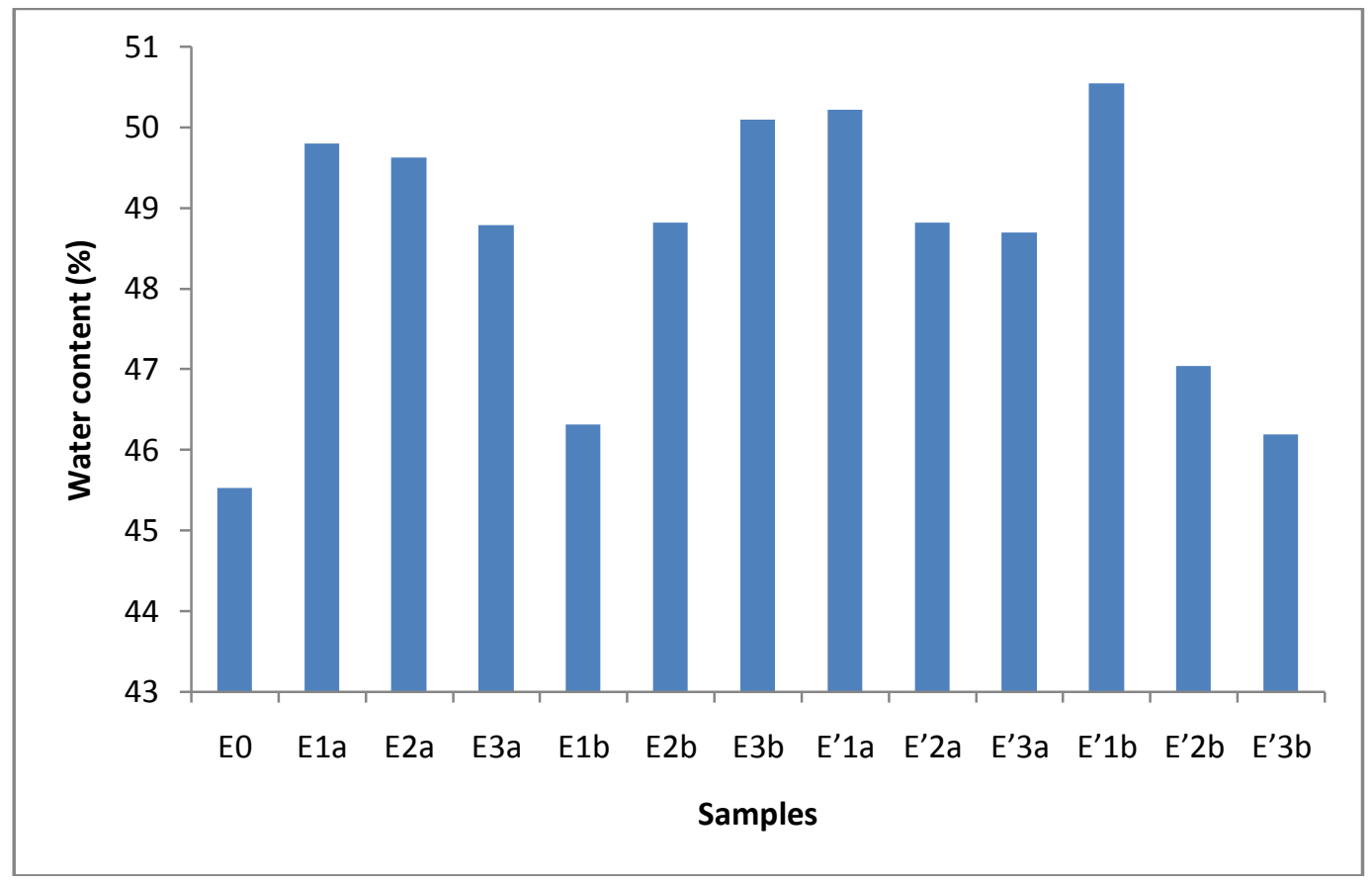

Figure 1:- Variation in water content according to the samples. 


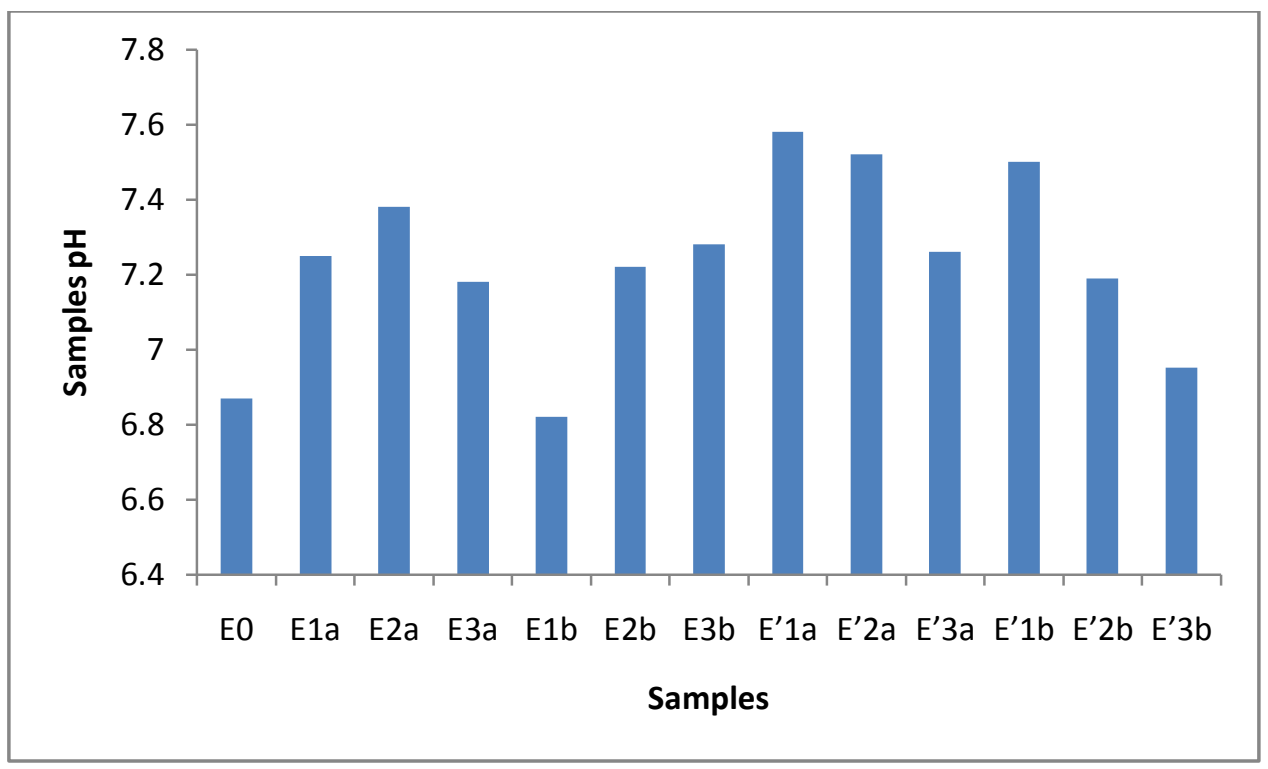

Figure 1:- Variation of $\mathrm{pH}$ depending on the samples.

\section{Microbiological quality of improved food broth:}

The presence of total aerobic mesophilic flora and Staphylococcus spp was noted in all the samples. The Sulfitoreducing anaerobes were counted in 05 samples out of 13 analyzed while fungal flora was present in 03 samples out of 13 analyzed. Total coliforms were absent in the all samples (tableau 3).

Table 3:- Microbiological characteristics (CFU / g) of the samples.

\begin{tabular}{|c|c|c|c|c|c|}
\hline Samples & $\begin{array}{l}\text { Total } \\
\text { flora }\end{array}$ & $\begin{array}{l}\text { Staphylococcus } \\
\text { spp. }\end{array}$ & $\begin{array}{l}\text { Sulphite-reducing } \\
\text { anaerobes }\end{array}$ & $\begin{array}{l}\text { Total } \\
\text { coliforms }\end{array}$ & $\begin{array}{l}\text { Yeasts and } \\
\text { molds }\end{array}$ \\
\hline $\mathbf{E}_{0}$ & $18.5 \times 10^{3}$ & $4.5 \times 10^{3}$ & $5.0 \times 10^{1}$ & $<1$ & $<1$ \\
\hline $\mathbf{E}_{1 \mathbf{a}}$ & $>300$ & $12.0 \times 10^{4}$ & $1.5 \times 10^{1}$ & $<1$ & $<1$ \\
\hline $\mathbf{E}_{2 \mathbf{a}}$ & $>300$ & $14.8 \times 10^{4}$ & $<10$ & $<1$ & $<1$ \\
\hline $\mathbf{E}_{3 \mathbf{a}}$ & $>300$ & $12.6 \times 10^{4}$ & $<10$ & $<1$ & $<1$ \\
\hline$E_{1 b}$ & $>300$ & $14.4 \times 10^{4}$ & $1.0 \times 10^{T}$ & $<1$ & $<1$ \\
\hline $\mathbf{E}_{2 \mathbf{b}}$ & $>300$ & $>300$ & $<10$ & $<1$ & $7.0 \times 10^{2}$ \\
\hline $\mathbf{E}_{3 \mathbf{b}}$ & $>300$ & $18.8 \times 10^{4}$ & $<10$ & $<1$ & $<1$ \\
\hline $\mathbf{E}_{1 \mathbf{a}}$ & $>300$ & $18.4 \times 10^{4}$ & $2.0 \times 10^{1}$ & $<1$ & $1.0 \times 10^{2}$ \\
\hline$E_{2 a}^{\prime a}$ & $15.9 \times 10^{4}$ & $5.2 \times 10^{4}$ & $<10$ & $<1$ & $<1$ \\
\hline $\mathbf{E}_{3 \mathbf{a}}$ & $20.6 \times 10^{4}$ & $2.0 \times 10^{4}$ & $<10$ & $<1$ & $<1$ \\
\hline $\mathbf{E}_{1 \mathrm{~b}}$ & $>300$ & $>300$ & $1.0 \times 10^{1}$ & $<1$ & $1.0 \times 10^{3}$ \\
\hline$E_{2 b}^{\prime}$ & $>300$ & $4.0 \times 10^{4}$ & $<10$ & $<1$ & $<1$ \\
\hline $\mathbf{E}_{3 b}^{\prime}$ & $>300$ & $2.0 \times 10^{4}$ & $<10$ & $<1$ & $<1$ \\
\hline $\begin{array}{l}\text { Criteria } \\
\text { (AFNOR) }\end{array}$ & $<10^{2}$ & $<10^{5}$ & $<10$ & $<10^{2}$ & - \\
\hline
\end{tabular}

- : Unspecified.

\section{Discussion:-}

Lanhouin, a traditional fermented fish-based condiment is processed in the coastal areas of West African countries including Benin, Togo, Ghana, Nigeria and Côte-d'Ivoire. It is mostly used as taste enhancer and flavouring agent in many types of dishes (Anihouvi et al., 2005; Kindossi et al., 2012). The raw materials used for lanhouin production include the fish and the salt, and the fermentation is spontaneous and uncontrolled (Anihouvi et al., 2012a).

In this, this technology has been revisited and improved by the production of broths improved by the use of extracts of aromatic plants.Microbiological analyzes have shown the presence of certain germs. The frequencies of contamination observed were close to close to those reported by Anihouvi et al. (2005) for "Lanhouin" samples collected in the south of Benin (45.6 and 59.9\%). These values were similar to those reported respectively by 
Essuman (1992) on the "Momone" a fermented fish from Ghana and by Anihouvi et al. (2006) on the "lanhouin". The results indicate the presenceof a total aerobic mesophilic flora in the various samples of "Lanhouin" broth. These results vary from $18.5 .10^{3}$ to $20.6 .10^{4} \mathrm{CFU} / \mathrm{g}$ and were higher than the threshold value recommended by the standard which is $10^{2} \mathrm{CFU} / \mathrm{g}$. Indeed, the total mesophilic aerobic flora reflects the general microbiological quality of a product. This microbial load more or less enumerated in the broth could result from the conditions of production of "lanhouin" (main component of the broth) and also from operations during the production of broths (molding of "Lanhouin" flour and drying in the open air ). Indeed, according to Dossou-Yovo et al. (2011), the production of "Lanhouin" generally takes place in a relatively unclean environment. These results relating to the total aerobic mesophilic flora are lower than those obtained by Kouakou et al. (2013) which were 4.8 \pm 0.08 . $10^{8} \mathrm{CFU} / \mathrm{g}$ and 6.7 $\pm 0.5 .10^{8} \mathrm{CFU} / \mathrm{g}$ for fermented fish (Adjuevan) obtained using two different methods.

Concerning Staphylococcus spp, their presence often results from the action of factors such as wind, dust and also contamination of human origin through handling and secretions (saliva, sweat), the results obtained range from 4.5.10 $0^{3}$ to $18.8 .10^{4} \mathrm{CFU} / \mathrm{g}$. This could always be explained by the non-compliance with hygienic rules and good manufacturing practices during the production of "lanhouin" and or manipulation during the production of broths. Thus, the presence of these germs in fermented products indicates the need to take hygienic measures capable of countering the risks linked to these types of microorganisms (Anihouvi et al., 2006; Kouakou et al., 2013). These results are all below the threshold value recommended by the standard which is $10^{5} \mathrm{CFU} / \mathrm{g}$ and higher than those obtained by Adjou et al. (2017) (<10 CFU / g) on fermented fish meal improved with oil of Pimenta racemosa.This can be explained by the presence of plant extracts in the broths. Indeed, the antibacterial effects of Curcuma longawidely proven staphylococci (Teow et al., 2016; Yadav et al., 2013; Afrose et al., 2015), can also be confirmed with obtainedresults. Thus, with a gradual increase (10 to 40\%) in the proportion of Turmeric, there is a gradual decrease in the microbial quantum $\left(18.4 .10^{4}\right.$ to $2 \cdot 0.10^{4}$ and $>300$ to $\left.2.0 .10^{4} \mathrm{CFU} / \mathrm{g}\right)$. Indeed, at the level of the samples E'1a and E'1b, each having $10 \%$ of turmeric powder, $18.4 .10^{4}$ and $>300 \mathrm{CFU} / \mathrm{g}$ were observed respectively, while for the samples $\mathrm{E}^{\prime} 2 \mathrm{a}$ and $\mathrm{E}^{\prime} 2 \mathrm{~b}$, each having $20 \%$ turmeric powder, 5.2.10 4 and $4.0 .10^{4} \mathrm{CFU} / \mathrm{g}$ are obtained respectively. For samples E' $3 a$ and E' $3 b$, each having $40 \%$ turmeric powder, there is again a reduction in staphylococcal germs $\left(2 \cdot 0 \cdot 10^{4} \mathrm{CFU} / \mathrm{g}\right)$.

The anaerobic sulfito-reducers being ubiquitous germs, their presence in the samples would probably be related to the manipulations carried out on the ground, as well as the presence of flies on the production sites, without forgetting the recycled salt and improperly stored which is used for production. The presence of these germs could also result from the broth drying operation. These results varying from $1.0 .10^{1} \mathrm{CFU} / \mathrm{g}$ to $5.0 .10^{1} \mathrm{CFU} / \mathrm{g}$, were higher than the threshold value recommended by the standard which i 10 CFU / g and contrary to those of DossouYovo et al., (2011) who had obtained a total absence of anaerobic bacteria on improved Lanhouins obtained from two different species of fish.

The microbial quantum of yeasts and molds varies from $1.10^{2}$ to $1.10^{3} \mathrm{CFU} /$ gand this on only three samples among the thirteen analyzed. In fact, out of the six samples containing Pimenta racemosa essential oil at different doses (1.5 $\mu \mathrm{l} / \mathrm{g}$ and $2.5 \mu \mathrm{l} / \mathrm{g}$ ), we count for samples E'1a and E'1b respectively of $1.10^{2} \mathrm{CFU} / \mathrm{g}$ and $1.10^{3} \mathrm{CFU} / \mathrm{g}$. On the other hand, on the six samples containing the essential oil of Cymbopogon citratus at different doses $(1.5 \mu \mathrm{l} / \mathrm{g}$ and $2.5 \mu \mathrm{l} / \mathrm{g}$ ), we count for the sample E2b a value of $7.10^{2} \mathrm{CFU} / \mathrm{g}$. This low rate of fungal growth obtained allows us to justify the strong antifungal activity of the essential oils used and could also be justified by the antibacterial activities of Curcuma longa.

These results were in agreement with those of Adjou et al., 2017 (<10 CFU / g) and Dègnon et al. (2019) who respectively showed the antifungal activities of Pimenta racemosa oils on "Lanhouin" floursand Cymbopogon citratusessential oil on Aspergillus species isolated from fermented fish. However, the growth observed on the three samples (E2b, E'1a and E'1b) could be linked to the persistence of essential oils. This presence of fungal flora could therefore come from the production of "lanhouin" which requires drying phases which is generally done in the open air where "lanhouin" is subjected to multiple sources of contamination, in particular dust and insects which are vectors of mold spores. This mold contamination can also be the result of poor hygiene practices during production, where trimmed fish are sometimes covered with old loincloths or jute bags and left to mature. Likewise, the storage and transport of the "lanhouin" is done in baskets line with these old loincloths or cement papers which serve to cover the "lanhouin". These results therefore show that, in the range of concentrations tested, the essential oil of Cymbopogon citratus is more effective on the fungal flora of cubic "lanhouin" broths, compared to the essential oil of Pimenta racemosa. 


\section{Conclusion:-}

In order to enhance the "lanhouin", a traditional food broth from Benin and limit the consumption of industrial cube broths which are not without consequences for the health of the consumer, this work made it possible to assess the effectiveness of essential oils of Cymbopogon citratus and Pimenta racemosa as well as that of Curcuma longa powder as bio-preservative agents in the preservation of the quality of improved "lanhouin" product. It appears from the results obtained that the essential oil of Cymbopogon citratus has proven antifungal properties on the fungal flora of "lanhouin", compared to the essential oil of Pimenta racemosa. We can deduce that this essential oil offers new perspectives in the promotion of "lanhouin" by the use of natural plant extracts.

\section{Références:-}

1. Afrose R., Saha S., Banu L., Ahmed A., Shahidullah A., Gani A., Ali M., 2015. Antibacterial effect of Curcuma longa (Tumeric) against Staphylococcus aureus and Escherichia coli. Mymensingh medical journal : MMJ. 24. 506-15.

2. Anihouvi V.B., Hounhouigan J.D., Ayernor G.S., 2005. Production et commercialisation du «lanhouin », un condiment à base de poisson fermenté du Golfe du Bénin. Cahiers Agricultures, 14(3): 323-329.

3. Anihouvi V.B., Ayernor G.S., Hounhouigan J.D., Sakyi-Dawson E., 2006. Quality characteristics of Lanhouin: A traditional processed fermented fish product in the Republic of Benin. African Journal of Food, Agriculture, Nutrition and Development, 6(1): 1-15.

4. Anihouvi V.B., Kindossi J., Hounhouigan J., Devillers J., Boucher B., Gabor E., Doucet D., 2014. Lanhouin poisson salé et fermenté, Guide Technique. AFTER/UE. 18p.

5. Ayoubi E. H., Failler P., 2013. Industrie des pêches et de l'aquaculture au Bénin. Industrie des pêches et de l'aquaculture dans la zone de la COMHAFAT. 5, 127p.

6. Dègnon R.G., Allagbé A.C., Adjou E.S., Dahouenon-Ahoussi E., 2019. Antifungal Activities of cymbopogon citratus Essential Oil against Aspergillus Species Isolated from Fermented Fish Products of Southern Benin. Journal of Quality and Hazards Control, 6(2): 53-57.

7. Dossou-Yovo P., Josse Roger G., Bokossa I., Palaguina I., 2011. Survey of the improvement of fish fermentation for lanhouin production in Benin. African Journal of Food Science, 5(17): 878-883.

8. Essuman K.M., 1992. Le poisson fermenté en Afrique : traitement, commercialisation et consommation. FAO, Document Technique de Pêches, 329, 80p.

9. Fall M., Diop M.B., Kantoussan J., Montet, D., Maiga A.S., Guiro A.T., 2018. Production halieutique au Sénégal : contribution de la transformation à l'économie maritime et nouvelles stratégies pour améliorer la fermentation traditionnelle du poisson. International Journal of Advanced Research, 6(5): 1371-1383.

10. FAO, 2016. Agreement on Port State Measures to Prevent, Deter and Eliminate Illegal, Unreported and Unregulated Fishing. Rome/Roma. 100p.

11. Kouakou AC, Kouadio FNG, Dadie AT, Montet D, Djè MK., 2013. Production et commercialisation de l'adjuevan, poisson fermenté de Côte d'Ivoire. Cah. Agric., 22 : 559-567.

12. Teow S., Liew K., Ali S., Khoo A., Peh S., 2016. Antibacterial action of Curcumin against Staphylococcus aureus : A brief review.

13. World Fish Centre, 2005. Le poisson et la sécurité alimentaire en Afrique. Egypte. 2p.

14. Yadav D., Yadav S., Khar R., Mujeeb M., Akhtar M., 2013. Tumeric ( Curcuma longa L.) : A promising spice for phytochemical and pharmacological activities.

15. Dossou-Yovo, P.D., Roger, J. G., Innocent, B., \& Iraïda, P. (2011). Survey of the improvement of fish fermentation for lanhouin production in Benin. African Journal of Food Science, 5(17), 878-883.

16. Burt, S. (2004). Essential oils: their antibacterial properties and potential applications in foods-a review. International journal of food microbiology, 94(3), 223-253.

17. Konfo, C. T. R., Chabi, N. W., Dahouenon-Ahoussi, E., Cakpo-Chichi, M., Soumanou, M. M., \& Sohounhloue, D. C. K. (2015). Improvement of African traditional sorghum beers quality and potential applications of plants extracts for their stabilization: a review. The Journal of Microbiology, Biotechnology and Food Sciences, 5(2), 190.

18. Bassolé H. N., kabore Z., TraoreK., 2001. Etude des profils bactériostatiques et bactéricides d'extraits végétaux vis-à-vis de germes pathogènes impliqués dans la contamination des denrées alimentaires d'origine animale. Pharm. Méd. Trad. Afr., 1l:113-

19. Clamay, 2016. Les bouillons cubes sont-ils dangereux pour la santé ? http://www.afrizap.com/bouillons/. 